\title{
Human epithelial cell death caused by Actinobacillus actinomycetemcomitans infection
}

\author{
SATSUKI KATO, KEISUKE NAKASHIMA, MAKI INOUE, JUN TOMIOKA, KOJI NONAKA, TATSUJI \\ NISHIHARA* and YUSUKE KOWASHI \\ Department of Periodontology, School of Dentistry, Health Sciences University of Hokkaido, Hokkaido and \\ * Department of Oral Science, National Institute of Infectious Diseases, Tokyo, Japan
}

\begin{abstract}
The gingival sulcus is the shallow crevice around the tooth, and its epithelium is a gateway for initial bacterial infection in periodontal disease. Recent studies have shown that Actinobacillus actinomycetemcomitans invades an epithelial cell line, KB cells, in vitro. The aim of the present study was to clarify the changes in KB cells after $A$. actinomycetemcomitans infection. The cytotoxic effects of $A$. actinomycetemcomitans on $\mathrm{KB}$ cells were determined at 72, 96 and $120 \mathrm{~h}$ after infection by an MTT assay. Nuclear morphological changes were observed by staining with Hoechst 33258. Cytoplasmic histone-associated DNA fragmentation in the infected KB cells was determined by ELISA. A. actinomycetemcomitans was cytotoxic on KB cells, and condensation and degradation of the nuclei were observed. DNA fragmentation was increased after the infection. In addition, $A$. actinomycetemcomitans showed similar cytotoxic effects on human gingival epithelial cells. The present study demonstrated that $A$. actinomycetemcomitans induces apoptotic cell death of oral epithelial cells in an in-vitro culture system. This induced apoptosis might be involved in the initiation and progression of periodontitis.
\end{abstract}

\section{Introduction}

The initial event in most bacterial diseases is microbial invasion of host cells and tissues. Epithelial cells act as the first barrier against this invasion. Invasion of the cells of the intestinal mucosa is an early step in the establishment of infection by enteric bacteria, including Shigella spp., Salmonella spp., Yersinia spp. and Escherichia coli $[1,2]$.

Actinobacillus actinomycetemcomitans is a gram-negative, capnophilic, fermentative coccobacillus which has been implicated in the pathogenesis of several forms of periodontal disease [3]. Christersson et al. detected the presence of antigens from $A$. actinomycetemcomitans in gingival tissues, indicating that this bacterium could invade the tissue of the periodontium in severe periodontal diseases [4]. Fives-Taylor et al. demonstrated that adhesion of the bacterium to $\mathrm{KB}$ cells is a rapid process which occurs within $15 \mathrm{~min}$ and that internalisation occurs through a cytochalasin D-sensi-

Received 7 July 1999; revised version received 20 Nov. 1999; accepted 22 Dec. 1999.

Corresponding author: Professor Y. Kowashi (e-mail: ykowashi @hoku-iryo-u.ac.jp). tive process in KB cells. Furthermore, the adhesion was found to involve multiple determinants and to be influenced by both bacterial and host environmental conditions $[5,6]$. However, these studies did not focus on changes in the infected $\mathrm{KB}$ cells.

An earlier study developed an in-vitro infection model for A. actinomycetemcomitans to provide evidence for the apoptotic cell death of murine macrophages after infection [7-9]. Therefore, the present study explored changes in $\mathrm{KB}$ cells after A. actinomycetemcomitans infection.

\section{Materials and methods}

Bacterial strains and growth conditions

Five strains of $A$. actinomycetemcomitans (ATCC 29523, Y4, JP2, NCTC 9710 and IDH 781) were used in this study. The test strains were grown in ToddHewitt Broth (Difco) supplemented with yeast extract $1 \% \mathrm{w} / \mathrm{v}$ at $37^{\circ} \mathrm{C}$ for 1 day in an atmosphere of $\mathrm{CO}_{2} 5 \%$ in air. Streptococcus mutans 33477 and S. salivarius 9227 were also grown in the same conditions as the $A$. actinomycetemcomitans strains. 


\section{Epithelial cells}

KB cells (ATCC CCL 17), an epithelial-like cell line originally isolated from a human oral epithelioid carcinoma, were maintained in Dulbecco's Modified Eagle's Medium (DMEM; Gibco BRL, Grand Island, NY, USA) supplemented with heat-inactivated fetal bovine serum (FBS; Gibco BRL) $10 \%$, penicillin $\mathrm{G}$ $100 \mathrm{U} / \mathrm{ml}$ and streptomycin $100 \mu \mathrm{g} / \mathrm{ml}$ at $37^{\circ} \mathrm{C}$ in $\mathrm{CO}_{2}$ $5 \%$ in air.

Human gingival epithelial cells (HGE cells) were also used in certain experiments. Healthy gingival tissue was obtained from patients undergoing surgery for removal of impacted teeth, after informed consent had been obtained. Specimens were cut into small pieces and incubated with Dispase (Godo Shusei, Tokyo, Japan) $0.4 \%$ overnight at room temperature. The surface epithelium was separated and placed in sterile phosphate-buffered saline (PBS) containing trypsin $0.05 \%$ and $0.53 \mathrm{mM}$ EDTA. Cells were collected by centrifugation, suspended in DMEM containing FBS $10 \%$ and incubated at $37^{\circ} \mathrm{C}$ in $\mathrm{CO}_{2} 5 \%$ in air. At confluence, the cells were trypsinised and re-seeded at $2 \times 10^{4}$ cells/well in a 96-well plate [10].

\section{Cytotoxicity assay}

$\mathrm{KB}$ cells were plated in a 96-well plate at a concentration of $2 \times 10^{4}$ cells/well $24 \mathrm{~h}$ before the experiment. A. actinomycetemcomitans Y4 was harvested by centrifugation and resuspended in DMEM without antibiotics. Bacterial suspension was added to the wells and the plates were centrifuged at $1000 \mathrm{~g}$ for $10 \mathrm{~min}$ at $4^{\circ} \mathrm{C}$ before incubation at $37^{\circ} \mathrm{C}$ for $1 \mathrm{~h}$ in an atmosphere of $\mathrm{CO}_{2} 5 \%$ in air. Cells infected at bacterium:cell ratios of 500:1, 5000:1 and 50000:1 were washed three times with DMEM containing penicillin $\mathrm{G}$, streptomycin and gentamicin $200 \mu \mathrm{g} / \mathrm{ml}$ to remove extracellular bacteria. The infected cells were cultured with DMEM containing FBS 5\% and antibiotics for 72, 96 and $120 \mathrm{~h}$. Stock MTT solution, 3 - [4, 5 - dimethylthiazol - 2 - yl $]$ - 2, 5 - diphenyltetrazolium bromide (Sigma) $2.5 \mathrm{mg} / \mathrm{ml}$, was added to the wells (20 $\mu \mathrm{l} /$ well), and the plates were incubated for $4 \mathrm{~h}$. After the addition of acid-isopropanol $(100 \mu \mathrm{l}$ of $0.04 \mathrm{~N}$ $\mathrm{HCl}$ in isopropanol) and thorough mixing, the plates were read on a microplate reader (TOSOH Microplate reader MRP A4i, Tokyo, Japan), with a test wavelength of $570 \mathrm{~nm}$ and a reference wavelength of $620 \mathrm{~nm}$. The percentage cytotoxicity was calculated by the following formula: $100 \times(1-$ optical density with infection/optical density without infection). Data were expressed as the mean and SD of tests performed in triplicate.

\section{Microscopic study}

$\mathrm{KB}$ cells were plated in a 24 -well plate $\left(1 \times 10^{5}\right.$ cells/well) for $24 \mathrm{~h}$ before the experiment and then infected with $A$. actinomycetemcomitans $\mathrm{Y} 4$ at a bacterium:cell ratio of 50000:1. After culture for $96 \mathrm{~h}$, infected KB cells were examined with a phasecontrast microscope (Olympus CK2, Tokyo, Japan). Nuclear morphological changes in the KB cells were also observed. The infected $\mathrm{KB}$ cells were fixed in a culture dish with methanol:acetic acid (3:1 v:v) at room temperature for $10 \mathrm{~min}$. After washing with PBS, the samples were incubated in Hoechst 33258 (Sigma) $0.1 \mathrm{mg} / \mathrm{ml}$ at $37^{\circ} \mathrm{C}$ for $10 \mathrm{~min}$ and observed by fluorescence microscopy $(365 \mathrm{~nm}$; Nikon UFX-DX, Tokyo, Japan).

\section{DNA fragmentation}

The infected $\mathrm{KB}$ cells $\left(2 \times 10^{4}\right.$ cells/well $)$ were cultured in 96-well culture plates in an atmosphere of $\mathrm{CO}_{2} 5 \%$ in air. After culture for $24 \mathrm{~h}$, the culture supernate was removed and measured for DNA fragmentation. Cell death detection by an enzymelinked immunosorbent assay (Cell death detection ELISA plus: Boehringer $\mathrm{GmbH}$, Mannheim, Germany) was used for the quantitative determination of cytoplasmic histone-associated DNA fragments, as described in the manufacturer's instructions. Data were expressed as the mean and SD of tests performed in triplicate.

\section{Results}

\section{Cytotoxic effects of $A$. actinomycetemcomitans}

A. actinomycetemcomitans cytotoxicity on $\mathrm{KB}$ cells was tested by an MTT assay. KB cells infected at a bacterium:cell ratio of 50000:1 showed 15.9 (SD $0.8) \%, \quad 34.9 \quad(\mathrm{SD} \quad 2.5) \%$ and $47.6 \quad$ (SD 1.5$) \%$ cytotoxicity after incubation for 72,96 and $120 \mathrm{~h}$, respectively (Fig. 1). The cytotoxic effects of five $A$. actinomycetemcomitans strains (ATCC 29523, Y4, JP2, NCTC 9710 and IDH 781) and S. mutans and $S$. salivarius were compared after incubation for $96 \mathrm{~h}$. All A. actinomycetemcomitans strains showed cytotoxic effects on the KB cells. However, S. mutans and $S$. salivarius showed only weak cytotoxic effects when compared with $A$. actinomycetemcomitans strains at the same bacterium:cell ratios (Fig. 2). The cytotoxic effects of $A$. actinomycetemcomitans $\mathrm{Y} 4$ on $\mathrm{KB}$ cells were further examined in the presence or absence of cytochalasin D (an inhibitor of actin polymerisation; $1 \mu \mathrm{g} / \mathrm{ml}$ ) and aurintricarboxylic acid (ATA; a DNA endonuclease inhibitor; $100 \mu \mathrm{M})$. After incubation for $96 \mathrm{~h}$, the cytotoxicity for control $\mathrm{KB}$ cells was 39.5 (SD 7.6)\%, and then decreased to 13.2 (SD 1.3)\% and 6.2 (SD 0.2)\% with the addition of cytochalasin D and ATA, respectively (Fig. 3).

\section{$D N A$ fragmentation in infected $K B$ cells}

Control KB cells showed absorbance values of 0.36 (SD 0.03). The KB cells infected at bacterium:cell 


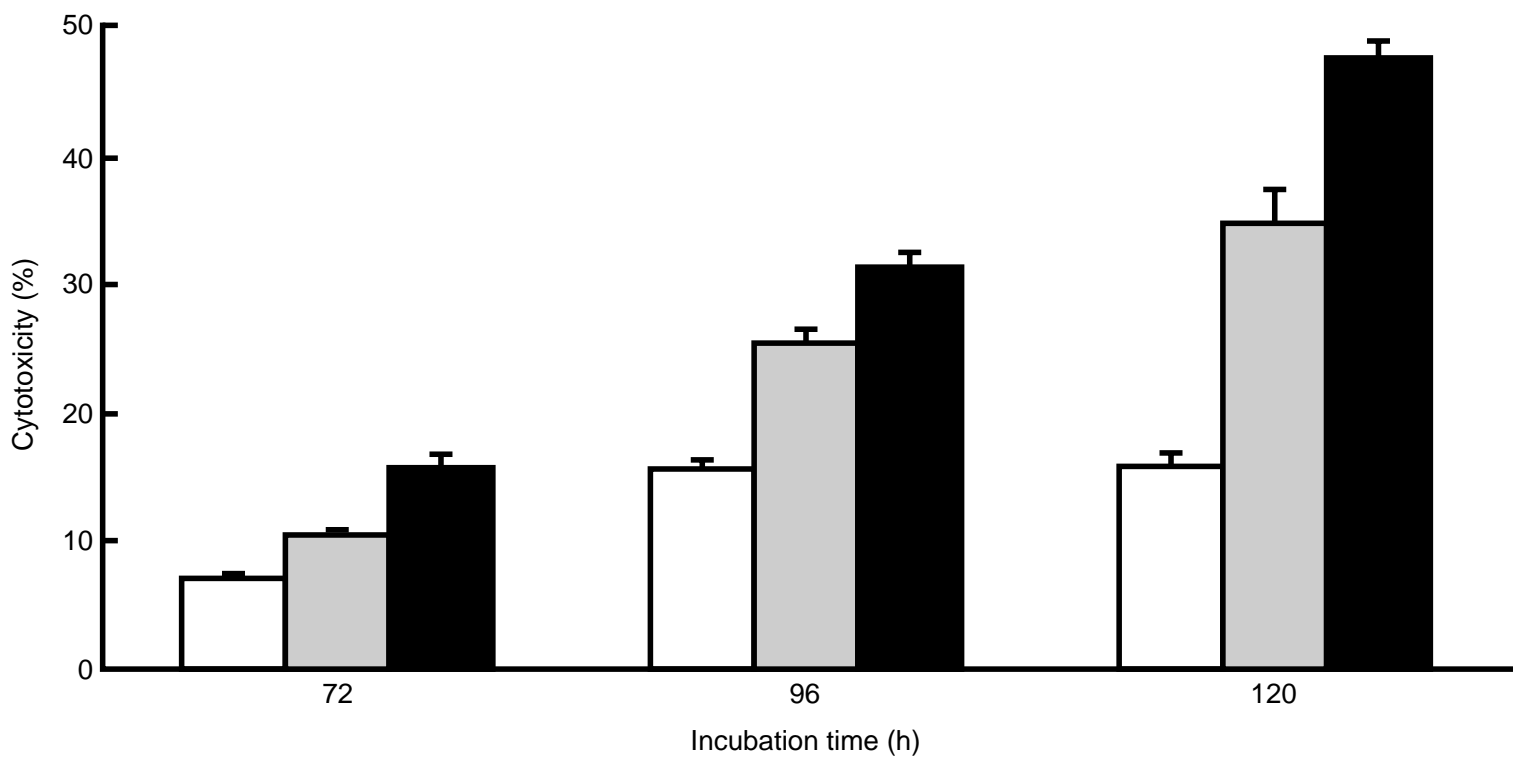

Fig. 1. Cytotoxic effect of A. actinomycetemcomitans $\mathrm{Y} 4$ on $\mathrm{KB}$ cells infected with A. actinomycetemcomitans $\mathrm{Y} 4$ at

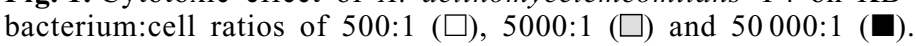

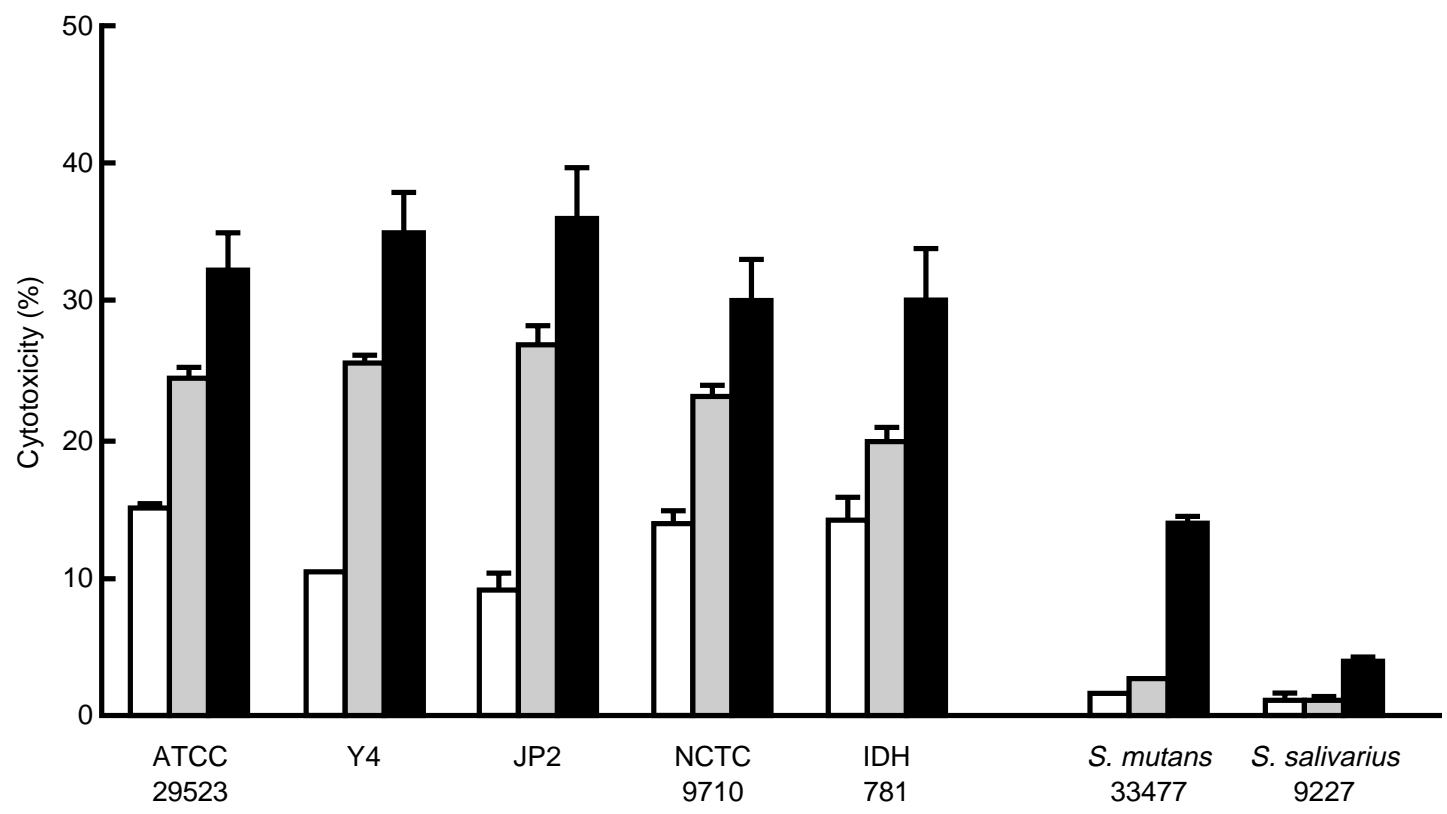

A. actinomycetemcomitans

Fig. 2. Cell death of KB cells induced by several strains of A. actinomycetemcomitans and streptococci. KB cells were infected with $A$. actinomycetemcomitans ATCC 29523, Y4, JP2, NCTC 9710, IDH 781, S. mutans 33477 and S.

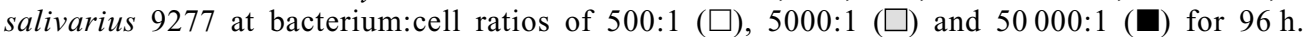

ratios of 500:1, 5000:1 and 50000:1 showed values of 0.54 (SD 0.04), 0.61 (SD 0.05) and 0.89 (SD 0.06), respectively (Fig. 4).

\section{Morphological changes in infected $K B$ cells}

Control KB cells grew as discrete cells and then coalesced to form confluent monolayers after incubation for $96 \mathrm{~h}$. The cells exhibited a 'cobble-stone' morphology, which is characteristic of homogeneous confluent epithelial monolayers (Fig. 5a). Infected KB cells were devoid of the characteristic features of control KB cells, as the infected cells were comparatively large, oddly shaped and had a multinucleate appearance (Fig. 5b). Infected KB cells were observed by fluorescence microscopy with Hoechst dye staining. In the control KB cells, Hoechst 33258 fluorescence was detected in chromatin in the nucleosomal structure of the nuclei (Fig. 5c). The apoptotic cells were identified according to characteristic cell morphologies, such as condensation and degradation of the nuclei (Fig. 5d). 


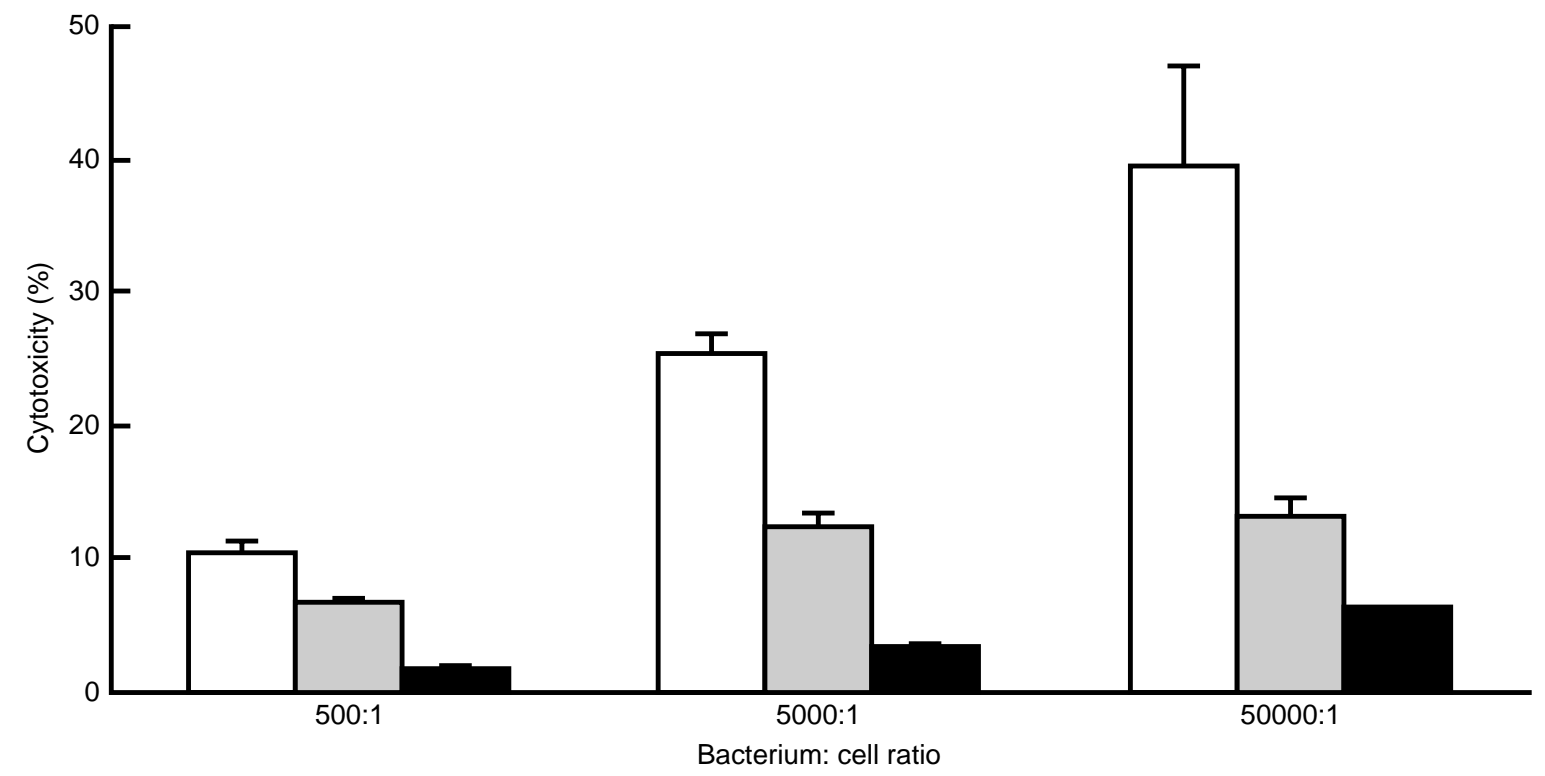

Fig. 3. Effects of cytochalasin D and ATA on the cytotoxicity of A. actinomycetemcomitans Y4 on KB cells infected at bacterium:cell ratios of 500:1, 5000:1 and 50000:1. The A. actinomycetemcomitans Y4-infected KB cells were cultured for $96 \mathrm{~h}$ : control $(\square)$, cytochalasin D $(1 \mu \mathrm{g} / \mathrm{ml} ; \square)$ and ATA $(100 \mu \mathrm{M} ; \mathbf{\square})$.

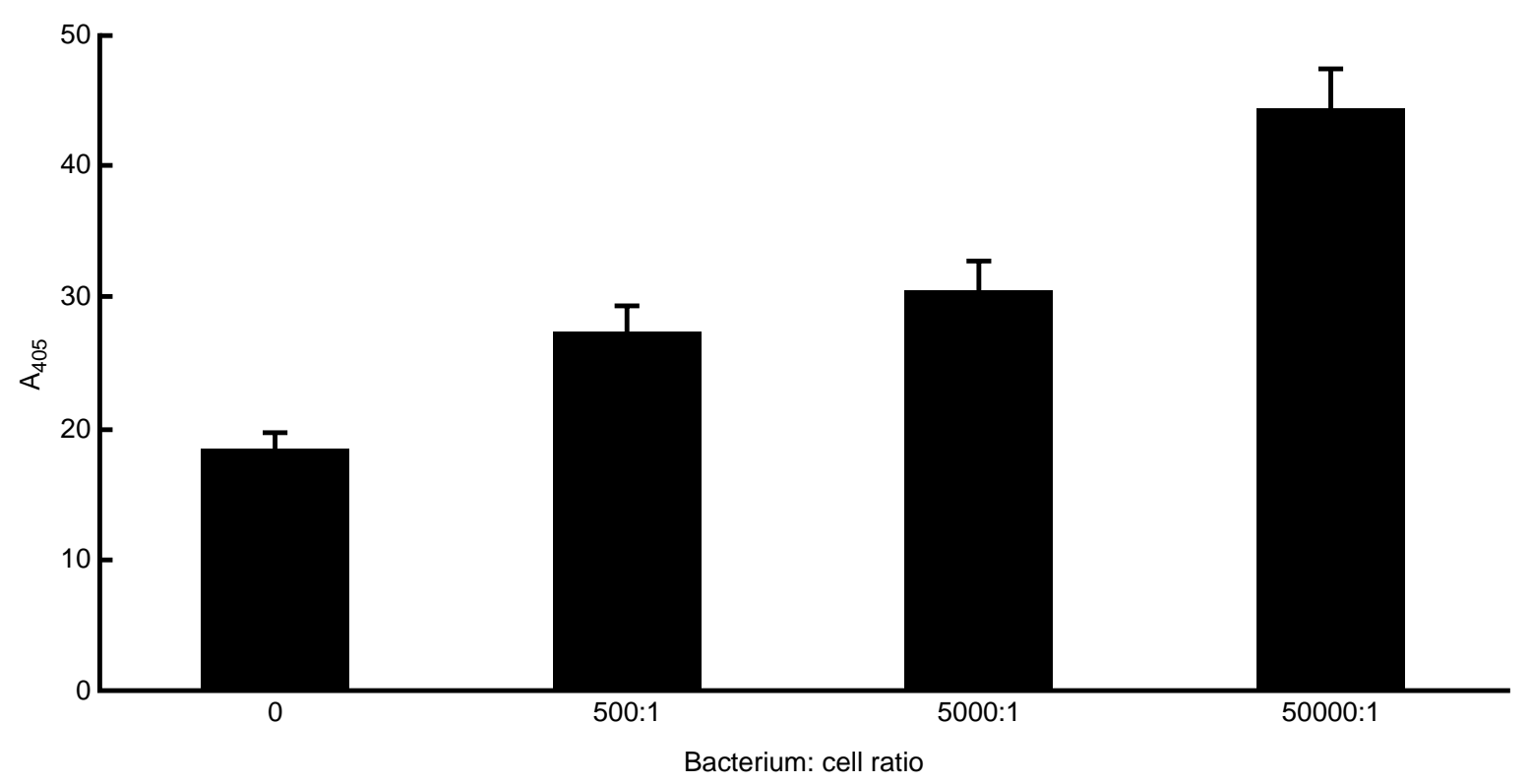

Fig. 4. DNA fragmentation of $\mathrm{KB}$ cells infected with A. actinomycetemcomitans Y4.

\section{Cytotoxic effects on human gingival epithelial cells}

A. actinomycetemcomitans Y4 showed 32.5 (SD 1.4)\% and 22.9 (SD 2.4)\% cytotoxicity for HGE cells (patients 1 and 2), respectively, at a bacterium:cell ratio of $50000: 1$, while this strain showed 31.2 (SD $1.3) \%$ cytotoxicity for KB cells (Fig. 6).

\section{Discussion}

Pathogenic microbes, including bacteria, bind to host cell surfaces and become internalised, forming the process called microbial invasion. Epithelial cell invasion is a strategy adopted by various pathogenic bacteria [11]. A. actinomycetemcomitans can invade periodontal tissue in periodontal diseases once colonisation by the bacterium has taken place $[12,13]$. Furthermore, A. actinomycetemcomitans can invade human oral epithelial cells [6].

The present study demonstrated death of KB cells after infection with A. actinomycetemcomitans Y4 (Fig. 1). An earlier study demonstrated that A. actinomycetemcomitans infection induced apoptotic cell death of the macrophage cell line J774.1 and that invasion by the bacterium was essential for the induction of apoptosis. The numbers of bacteria required to induce death of the $\mathrm{KB}$ cells were 10 times higher in the present study 

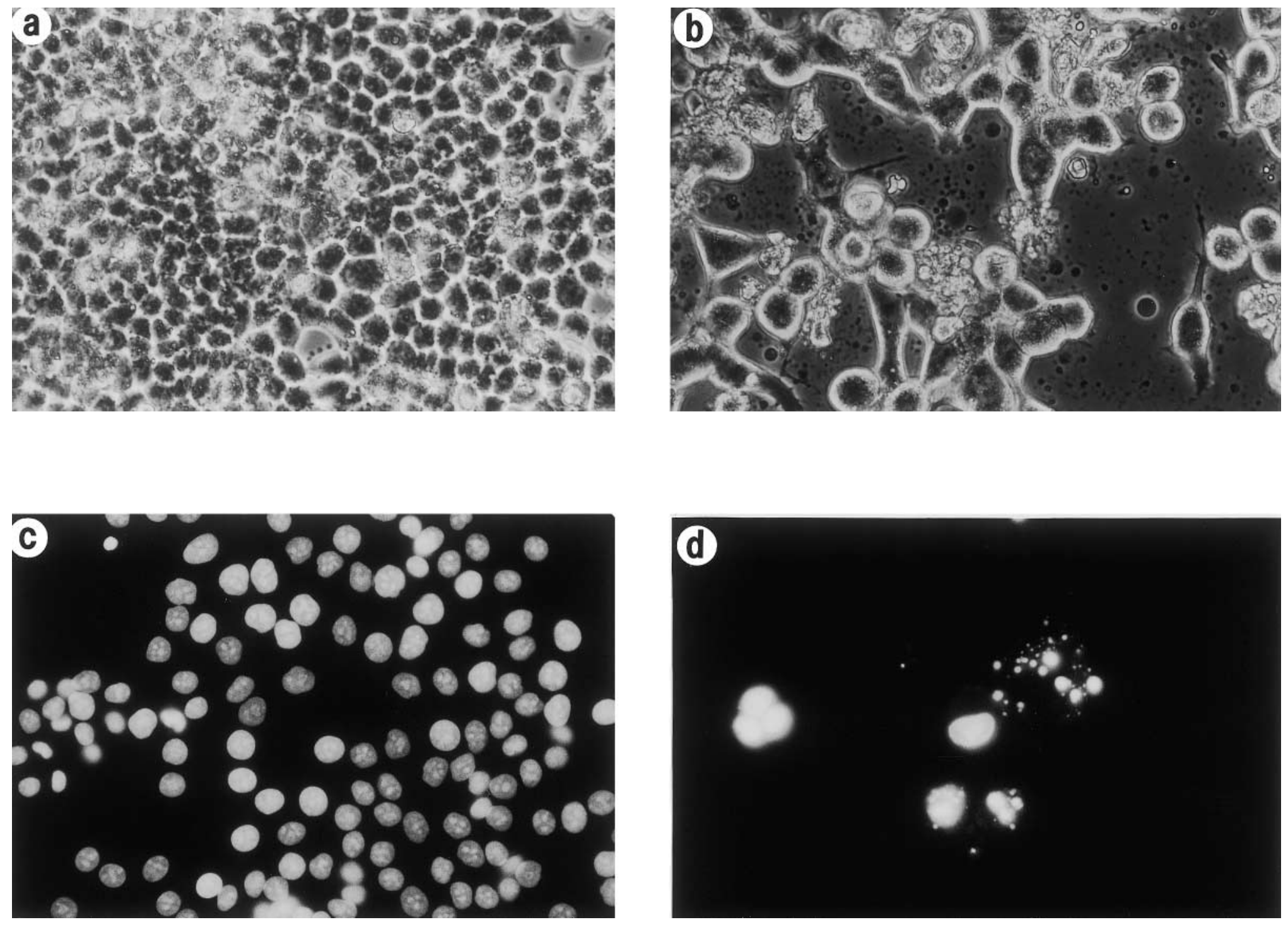

Fig. 5. Apoptotic morphology induced by A. actinomycetemcomitans Y4 infection. Phase-contrast micrographs of KB cells infected with A. actinomycetemcomitans Y4 (a, control KB cells; $\mathbf{b}, \mathrm{KB}$ cells infected at a bacterium:cell ratio of 50000:1) and cytochemical staining of KB cells infected with $A$ actinomycetemcomitans Y4 (c, control KB cells; d, KB cells infected at a bacterium:cell ratio of 50000:1) with the DNA-specific fluorochrome Hoechst 33258. Magnification: $\times 160$ (a,b), $\times 80$ (c,d). 


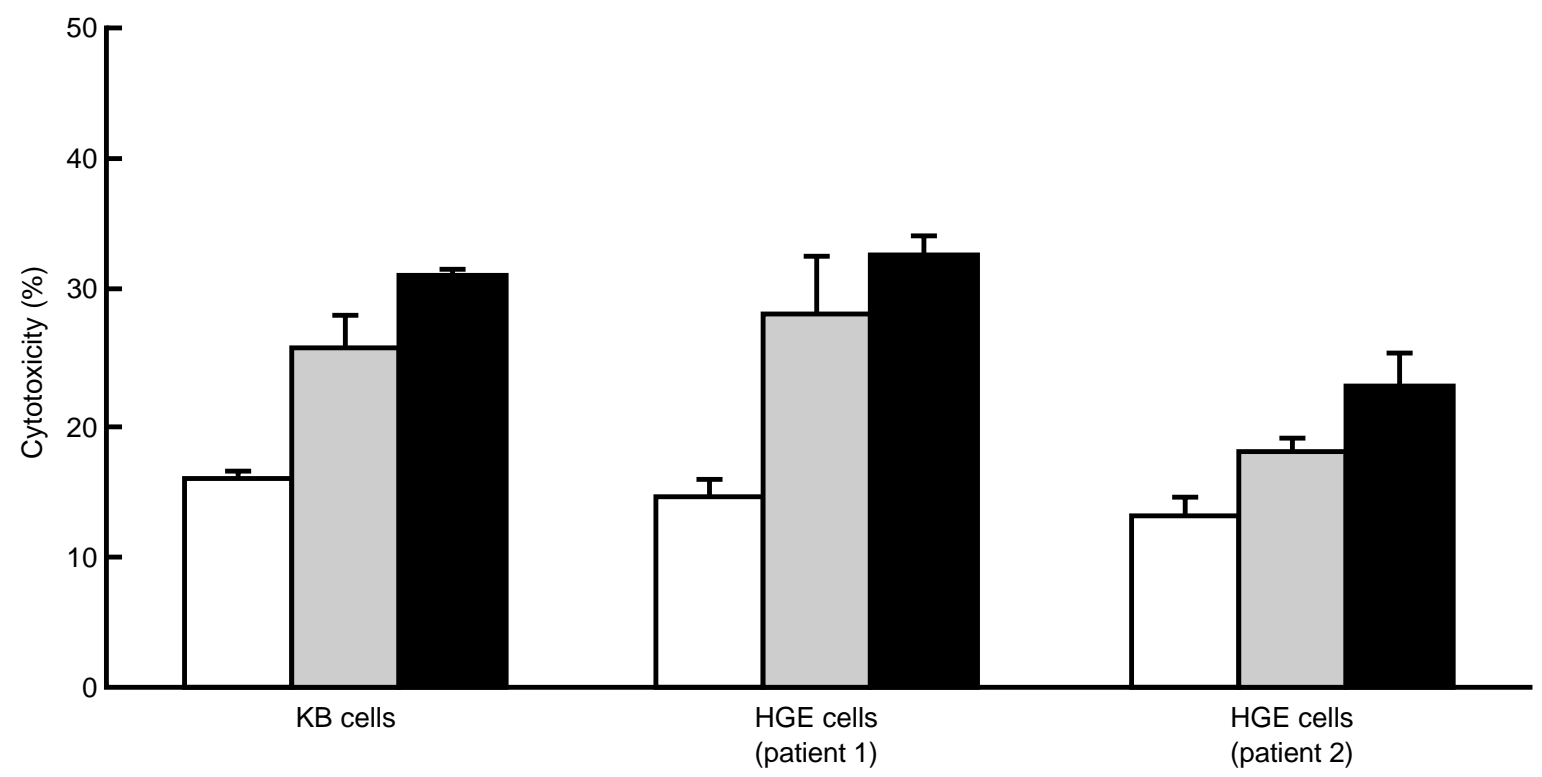

Fig. 6. Cytotoxic effects of $A$. actinomycetemcomitans Y4 on human gingival epithelial (HGE) cells infected with $A$. actinomycetemcomitans $\mathrm{Y} 4$ at bacterium:cell ratios of 500:1 ( $\square$ ), 5000:1 ( $\square$ ) and 50000:1

than those for J774.1 cells. Furthermore, the cytotoxic effects of $A$. actinomycetemcomitans Y4 on J774.1 cells appeared at $24 \mathrm{~h}$ after infection, whereas those on $\mathrm{KB}$ cells appeared at $72 \mathrm{~h}$. These data may indicate a greater resistance of epithelial cells to bacterial infections. Recent studies suggest that leucotoxin kills human immune cells by a pathway resembling apoptosis $[14,15]$. Two leucotoxic strains, A. actinomycetemcomitans ATCC 29523 and JP2, were used in this study. However, these two strains produced similar cytotoxic effects on $\mathrm{KB}$ cells to $\mathrm{Y} 4$, a non-leucotoxic strain (Fig. 2). Therefore, leucotoxin does not explain the ability of $A$. actinomycetemcomitans to induce cytotoxic effects on KB cells. Cytochalasin D significantly inhibited the cytotoxicity of A. actinomycetemcomitans $\mathrm{Y} 4$ on $\mathrm{KB}$ cells (Fig. 4), indicating that the cytotoxicity occurs through a microfilament-dependent process and that A. actinomycetemcomitans is cytotoxic only when it is inside the cytoplasm. Scanning electron microscopy demonstrated that the bacterium can adhere to $\mathrm{KB}$ cells and seems to invade them (data not shown). Fives-Taylor et al. also provided similar evidence for the invasion of $\mathrm{KB}$ cells by $A$. actinomycetemcomitans and determined that its invasion occurs through cytochalasin $\mathrm{D}$-sensitive processes [16].

In the present study, A. actinomycetemcomitans Y4infected $\mathrm{KB}$ cells exhibited the characteristics of apoptosis linked to the activation of an internucleosomal nuclease. ATA efficiently increased the percentage of viable KB cells infected with A. actinomycetemcomitans Y4 (Fig. 3). The nuclei of the infected KB cells showed chromatin condensation and other morphological alterations seen in apoptotic cells (Fig. 5d). Similar findings were observed for those cells infected at a bacterium:cell ratio of 500:1 (data not shown). Apoptotic cell death of the infected KB cells was also confirmed by quantitative cell death detection ELISA (Fig. 4). These findings suggest that the death of KB cells infected with $A$. actinomycetemcomitans Y4 occurs through apoptosis mediated by a cDNA endonuclease. Furthermore, HGE cells infected with A. actinomycetemcomitans also showed cytotoxicity similar to that seen in KB cells (Fig. 6).

A. actinomycetemcomitans has been considered to be an aetiological agent of periodontal disease, especially in the localised form of juvenile periodontitis (LJP). The most striking feature of LJP is the lack of clinical inflammation, despite the presence of deep periodontal pockets and vertical loss of alveolar bone around the first molars and incisors. The results of the present study suggest that the periodontal pathogen $A$. actinomycetemcomitans can invade gingival epithelium by stealth without inflammation, by inducing apoptotic cell death of the epithelial cells. Destruction of the first-step defensive structure of living gingival epithelial cells could lead to an initiation of infection and further the development of periodontal inflammation. The detailed pathways of apoptosis mediated by cDNA endonuclease, as well as the adhesion of bacteria to epithelial cell surfaces, destruction of the cell membrane and infiltration into epithelial cell cytoplasm, should be investigated further.

This work was supported by a grant-in-aid for scientific research (no. 11771363) from the Ministry of Education, Science Research and Culture of Japan.

\section{References}

1. Gibbons RJ. Bacterial adhesion to oral tissues: a model for infectious diseases. J Dent Res 1989; 68: 750-760.

2. Sansonetti PJ, Mounier J, Prévost MC, Mège RM. Cadherin expression is required for the spread of Shigella flexneri between epithelial cells. Cell 1994; 76: 829-839. 
3. Zambon JJ, Christersson LA, Slots J. Actinobacillus actinomycetemcomitans in human periodontal disease. Prevalence in patient groups and distribution of biotypes and serotypes within families. J Periodontol 1983; 54: 707-711.

4. Christersson LA, Wikesjo UM, Albini B, Zambon JJ, Genco RJ. Tissue localization of Actinobacillus actinomycetemcomitans in human periodontitis. II. Correlation between immunofluorescence and culture techniques. J Periodontol 1987; 58: $540-545$.

5. Fives-Taylor P, Meyer D, Mintz K. Characteristics of Actinobacillus actinomycetemcomitans invasion of and adhesion to cultured epithelial cells. Adv Dent Res 1995; 9: 55-62.

6. Fives-Taylor P, Meyer D, Mintz K. Virulence factors of the periodontopathogen Actinobacillus actinomycetemcomitans. J Periodontol 1996; 67 Suppl: 291-297.

7. Kato S, Muro M, Akifusa S et al. Evidence for apoptosis of murine macrophages by Actinobacillus actinomycetemcomitans infection. Infect Immun 1995; 63: 3914-3919.

8. Muro M, Koseki T, Akifusa S et al. Role of CD14 molecules in internalization of Actinobacillus actinomycetemcomitans by macrophages and subsequent induction of apoptosis. Infect Immun 1997; 65: 1147-1151.

9. Nonaka K, Ishisaki A, Muro M et al. Possible involvement of protein kinase $\mathrm{C}$ in apoptotic cell death of macrophages infected with Actinobacillus actinomycetemcomitans. FEMS Microbiol Lett 1998; 159: 247-254.

10. Oshima M, Taguchi M, Ogoshi T, Fujiwara K, Ito K, Otsuka $\mathrm{K}$. Stimulation of human periodontal ligament fibroblast collagenase production by a gingival epithelial cell-derived factor. J Periodont Res 1995; 30: 220-228.

11. Boyer B, Thiery JP. Epithelial cell adhesion mechanisms. J Membrane Biol 1989; 112: 97-108.

12. Falkow S, Isberg RR, Portnoy DA. The interaction of bacteria with mammalian cells. Annu Rev Cell Biol 1992; 8: 333-363.

13. Saglie FR, Carranza FA, Newman MG, Cheng L, Lewin KJ. Identification of tissue-invading bacteria in human periodontal disease. J Periodont Res 1982; 17: 452-455.

14. Mangan DF, Taichman NS, Lally ET, Wahl SM. Lethal effects of Actinobacillus actinomycetemcomitans leukotoxin on human T lymphocytes. Infect Immun 1991; 59: 3267-3272.

15. Korostoff J, Wang J-F, Kieba I, Miller M, Shenker BJ, Lally ET. Actinobacillus actinomycetemcomitans leukotoxin induces apoptosis in HL-60 cells. Infect Immun 1998; 66: 4474-4483.

16. Meyer DH, Sreenivasan PK, Fives-Taylor PM. Evidence for invasion of a human oral cell line by Actinobacillus actinomycetemcomitans. Infect Immun 1991; 59: 2719-2726. 